\title{
Short communication: Profile of virulence factors of Staphylococcus aureus isolated from subclinical bovine mastitis in the state of Rio de Janeiro, Brazil
}

\author{
S. M. O. Coelho, I. A. Pereira, L. C. Soares, B. R. Pribul, and M. M. S. Souza1 \\ Veterinary Bacteriology Laboratory, Department of Veterinary Microbiology and Immunology, Veterinary Institute, \\ Universidade Federal Rural do Rio de Janeiro, 23890-000 Brazil
}

\begin{abstract}
Staphylococcus aureus produces exoproteins that contribute to its ability to colonize the mammary gland such as hemolysins, coagulase, slime, and protein A. This study characterized phenotypically and genotypically these virulence factors in 50 Staph. aureus isolates. These isolates were obtained from milk samples from subclinical mastitis cases identified in 15 dairy cattle farms located in the state of Rio de Janeiro, Brazil. All of the confirmed Staph. aureus samples were PCR positive for the coa gene, which displayed 3 different size polymorphisms. The amplification of the spaA X region yielded a single amplicon for each isolate with the prevalent amplicon sized 315 bp. The Staph. aureus isolates were 24 and $16 \%$ positive for the $h l a$ and $h l b$ genes, respectively, and 22 and $20 \%$ positive for the $i c a A$ and $i c a D$ genes, respectively. Amplification of the agr gene RNAIII was positive in $74 \%$ of the strains. Twenty-seven different profiles were identified among the samples, indicating a great diversity of Staph. aureus involved in the etiology of mastitis cases in the analyzed region. These findings are valuable to the comprehension of the distribution of the profiles of Staph. aureus strains isolated from subclinical mastitis cases in the state of Rio de Janeiro.
\end{abstract}

Key words: Staphylococcus aureus, virulence factor, bovine mastitis

\section{Short Communication}

Staphylococcus aureus is a ubiquitous pathogen that causes a variety of infections in humans and animals. It is recognized as a major pathogen causing subclinical IMI in dairy cows, which may lead to severe economic losses worldwide (Godden et al., 2002). In Brazil, Staph. aureus isolates are commonly recovered from bovine mastitic milk samples (Coelho et al., 2009). The molecular process responsible for the disease manifesta-

Received March 4, 2010.

Accepted March 20, 2011.

${ }^{1}$ Corresponding author: miliane@ufrrj.br tion are poorly understood but presumed to be caused partially by differences in gene content and by allelic variations between Staph. aureus strains. Nevertheless, little information is available about the genetic diversity of Staph. aureus isolated from cows with mastitis. This bacterium produces a range of virulence factors that contribute to its ability to colonize the mammary gland, including hemolysins, slime, protein A, and coagulase.

The $\alpha$ - and $\beta$-hemolysins are the most important factors in the pathogenesis of IMI. The $\beta$-toxin is an $\mathrm{Mg}^{2+}$-dependent sphingomyelinase $\mathrm{C}$, which degrades sphingomyelin in the outer phospholipid layer of the membrane (Linehan et al., 2003).

The adherence and fixation of Staph. aureus on biological surfaces represent the fundamental steps in the development of infections. The production of slime mediates adhesion to implanted surfaces acting as a cementing matrix, making bacteria less accessible to the host's defense system (Coelho et al., 2009). Slime production is controlled by the ica operon (icaADBC) and the co-expression of the $i c a A$ and $i c a D$ genes leads to a significant increase in such production (Arciola et al., 2001).

Staphylococcal protein A is a membrane-bound exoprotein characterized and well known for its ability to bind to the fragment crystallizable $(\mathrm{Fc})$ region of immunoglobulins of most mammalian species. This protein is encoded by the spaA gene with a polymorphic (X) and a conserved region. The polymorphic $\mathrm{X}$ region consists of a variable number of repeated 24 pairs of bases located in the coding region for the cellular wall C-terminal extremity (Koreen et al., 2004).

The coagulase protein has the ability to turn fibrinogen into fibrin threads by a mechanism different from natural clotting. Coagulase has also been shown to be a virulence factor in IMI. This protein is encoded by the coa gene, which possesses a conserved and a repeated polymorphic region that can be used to measure relatedness between Staph. aureus isolates. This region consists of repeated short sequences of $81 \mathrm{bp}$ that are variable in number and sequence, and a fixed sequence of $330 \mathrm{bp}$ (Reinoso, 2004). 
The accessory gene regulator $(a g r)$ operon (agrA, $\operatorname{agr} B$, $\operatorname{agr} C \operatorname{agr} D$, and $h l d$ ) is recognized as a quorumsensing gene cluster that upregulates production of secreted virulence factors such as $\alpha$ - and $\beta$-hemolysins, proteases, DNase, and sphingomyelinase. This same cluster also downregulates the production of cell-associated virulence factors in a cell density-dependent manner in Staph. aureus (Lyon et al., 2000). The agr locus comprises 2 divergent transcriptional units under the control of the promoters P2 (RNA II) and P3 (RNA III). The P3 transcript, an RNA III molecule, mediates the upregulation of secreted virulence factors as well as the downregulation of surface proteins (Novick, 2000).

These virulence factors have significant importance through the different stages of mastitis pathogenesis; hence, the aim of the present study was to characterize these factors phenotypically and genotypically in Staph. aureus strains isolated from subclinical mastitis cases in the state of Rio de Janeiro, Brazil. The continuous addition of information about this bacterium represents a valuable source for understanding the genetic diversity of Staph. aureus and can contribute to new strategies toward decreasing the spread of infection.

Twenty-five dairy cattle farms located in 6 different towns, comprising an important milk production region of the state of Rio de Janeiro, Brazil, were selected to be in this study due to its medium size comprising an average of $1,500 \mathrm{~L}$ of milk daily, mechanical milking system, and veterinary management. A total of 450 animals were evaluated for subclinical mastitis through the California Mastitis Test (CMT). Out of this total number, 280 cows presented positive results after the CMT, among which 57 cows were evaluated through 228 milk samples, representing $20 \%$ of the 280 investigated CMT-positive cases. Staphylococcus spp. were detected in 150 of these milk samples and Staph. aureus was detected in 50 of them (34\%). Each Staph. aureus was isolated from a single cow, meaning that 50 of the above-mentioned 57 cows were Staph. aureus positive. After bacteriological and genotypic analyses, Staphylococcus intermedius (27\%, $\mathrm{n}=40)$, Staphylococcus hyicus $(20 \%, \mathrm{n}=31)$, and Staphylococcus schleiferi coagulans $(19 \%, \mathrm{n}=29)$ were also detected.

Milk samples were aseptically collected and transported to the laboratory in coolers with ice $\left(4-8^{\circ} \mathrm{C}\right)$ for the bacteriological analyses. These samples were incubated at $37^{\circ} \mathrm{C}$ for $6 \mathrm{~h}$ and plated in duplicate in sheep blood agar (Oxoid Brasil Ltda, São Paulo-SP, Brazil), with one sample being incubated in aerobic conditions for $24 \mathrm{~h}$ and the duplicate sample being incubated in anaerobic conditions for 24 to $48 \mathrm{~h}$ at $37^{\circ} \mathrm{C}$. The colonies were identified according to routine microbiological diagnostics, including cultural properties, catalase, coagulase, detection of hemolysis, maltose fermentation, acetoin production, and nitrate reduction (Koneman et al., 2005).

The Staph. aureus production of slime was detected using the Christensen et al. (1985) methodology. The adherence of each isolate to the surface of microplates has been determined quantitatively by a method standardized in our laboratory. They were also cultured in Congo red agar (CRA) and the black colonies were considered as normal slime producer strains, whereas the red ones were considered as strains unable to produce slime (Arciola et al., 2001).

To detect the production of $\alpha$ - and $\beta$-hemolysins, Staph. aureus isolates were radially streaked in sheep blood agar for evaluation of the type of hemolysis (Demo, 1996). Hemolytic synergism was determined by the cultivation of isolates in sheep blood agar at $37^{\circ} \mathrm{C}$ for $24 \mathrm{~h}$ in the presence of $\beta$-toxin from Staph. aureus (Demo, 1996).

Staphylococcus aureus DNA was extracted according to the methodology described in Coelho et al. (2009). Polymerase chain reaction analysis of the coa, spa (region $\mathrm{X}$ ), icaA, icaD, hla, hlb, agr (rnaIII gene), and rDNA genes were carried out using the primers, amplification cycles, and references described in Table 1. The reactions were performed in a final volume of 20 $\mu \mathrm{L}$, containing PCR buffer $(10 \mathrm{~m} M$ Tris $\mathrm{HCl}, \mathrm{pH} 9.0$;

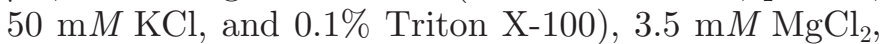
$250 \mu \mathrm{mol}$ of each of the deoxynucleoside triphosphates, $3.0 \mu \mathrm{mol}$ of each gene-specific primer, $2.5 \mathrm{U}$ of Taq DNA Polymerase (Promega, Madison, WI), and $5 \mu \mathrm{L}$ of template (Reinoso, 2004). The hla and hlb genes were amplified by a PCR multiplex modified from the method described in Adhikari et al. (2002). Isolates from our collection that were previously characterized were used as controls in the assays.

The Staph. aureus isolates confirmed by PCR amplification by the 23S rDNA (Reinoso, 2004) were phenol and genotypically characterized by the presence of virulence factors. Correlation between the phenotypic and genotypic results were determined by the $\chi^{2}$ and Fisher tests $(\mathrm{IC}=95 \%)$.

Slime production was detected in $80 \%$ (40/50) of the Staph. aureus strains by the microplate test. In addition, the CRA assay revealed that $24 \%(12 / 50)$ presented black colonies, characterizing positive strains; $34 \%$ $(17 / 50)$ were considered almost black (an intermediate variant); and $42 \%(21 / 50)$ were red variants, characterizing nonproducer strains. The PCR for the icaA $(1,315$ bp) and icaD (381 bp) genes were positive in $7(14 \%)$ and $6(12 \%)$ isolates, respectively (Figure 1) and both genes were detected in 4 isolates $(7.3 \%)$. The $i c a$ locus is a virulence marker for clinically significant staphylococcal isolates, which is required for the synthesis of the intracellular polysaccharide adhesin by staphylococci, 
Table 1. Sequences of oligonucleotide primers with corresponding programs

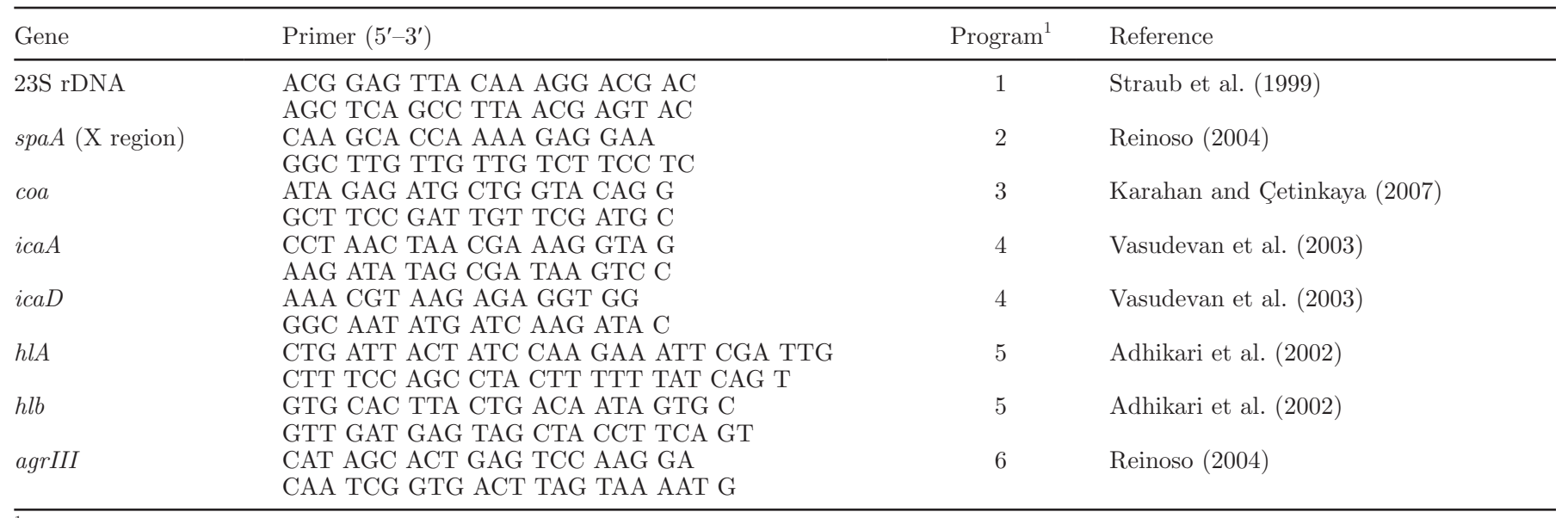

${ }^{1} 1=37 \times\left(94^{\circ} \mathrm{C}\right.$ for $40 \mathrm{~s}, 64^{\circ} \mathrm{C}$ for $60 \mathrm{~s}, 72^{\circ} \mathrm{C}$ for $\left.75 \mathrm{~s}\right) ; 2=30 \times\left(94^{\circ} \mathrm{C}\right.$ for $60 \mathrm{~s}, 60^{\circ} \mathrm{C}$ for $60 \mathrm{~s}, 72^{\circ} \mathrm{C}$ for $\left.60 \mathrm{~s}\right) ; 3=30 \times\left(94^{\circ} \mathrm{C}\right.$ for $60 \mathrm{~s}, 58^{\circ} \mathrm{C}$ for $60 \mathrm{~s}, 72^{\circ} \mathrm{C}$ for $\left.60 \mathrm{~s}\right) ; 4=30 \times\left(92^{\circ} \mathrm{C}\right.$ for $45 \mathrm{~s}, 49^{\circ} \mathrm{C}$ for $45 \mathrm{~s}, 72^{\circ} \mathrm{C}$ for $\left.1 \mathrm{~min}\right) ; 5=94^{\circ} \mathrm{C}$ for $5 \mathrm{~min}, 30 \times\left(94^{\circ} \mathrm{C}\right.$ for $60 \mathrm{~s}, 50^{\circ} \mathrm{C}$ for $60 \mathrm{~s}, 72^{\circ} \mathrm{C}$ for 60 $\mathrm{s}), 72^{\circ} \mathrm{C}$ for $7 \mathrm{~min} ; 6=94^{\circ} \mathrm{C}$ for $3 \mathrm{~min}, 30 \times\left(94^{\circ} \mathrm{C}\right.$ for $60 \mathrm{~s}, 55^{\circ} \mathrm{C}$ for $60 \mathrm{~s}, 72^{\circ} \mathrm{C}$ for $\left.60 \mathrm{~s}\right) 72^{\circ} \mathrm{C}$ for $7 \mathrm{~min}$.
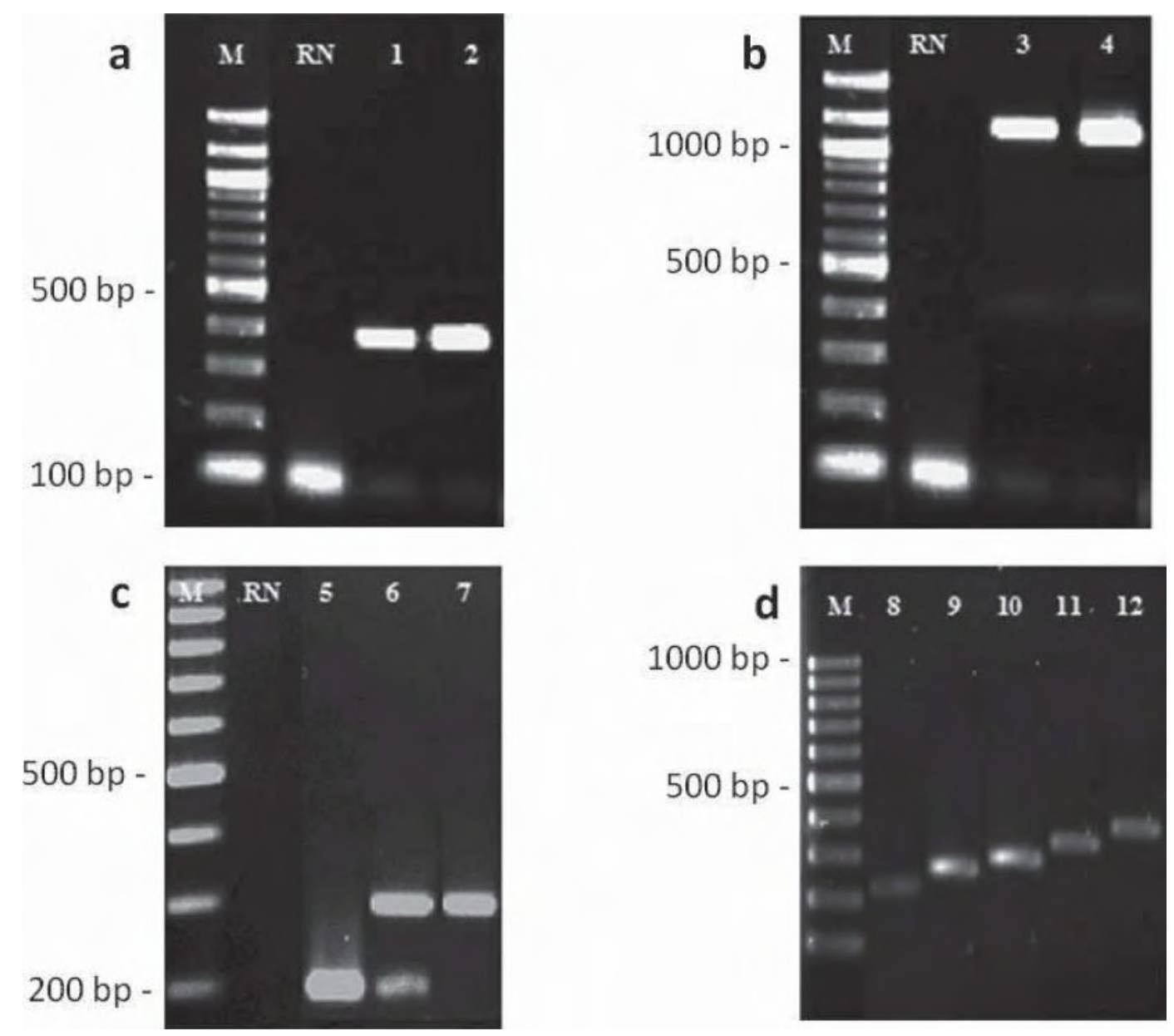

Figure 1. Agarose (1.5\%) gel electrophoresis of Staphylococcus aureus PCR products of virulence factor genes. M = molecular weight standard; $\mathrm{RN}=$ negative reaction; (a) $1=i c a D$-positive isolate $(381 \mathrm{bp}), 2=$ control reaction; (b) $3=i c a A$-positive isolate $(1,315 \mathrm{bp}), 4=$ control reaction; (c) $5=h l a$-positive isolate $(210 \mathrm{bp}), 6=$ positive isolate for both genes $(h l a$ and $h l b), 7=h l b$-positive isolate $(300 \mathrm{bp}) ;(\mathrm{d}) 8=s p a A$ positive isolate (polymorphic region; $220 \mathrm{bp}), 9=s p a A$-positive isolate $(250 \mathrm{bp}), 10=$ spa $A$-positive isolate $(280 \mathrm{bp}), 11=s p a A$-positive isolate (300 bp); and $12=$ spaA-positive isolate $(315 \mathrm{bp})$. 
Table 2. Staphylococcus aureus characterization considering the presence $(+)$ or absence $(-)$ of $h l a, h l b, i c a A$, icaD, and rnaIII genes and the polymorphisms of spaA and coa genes in different farms

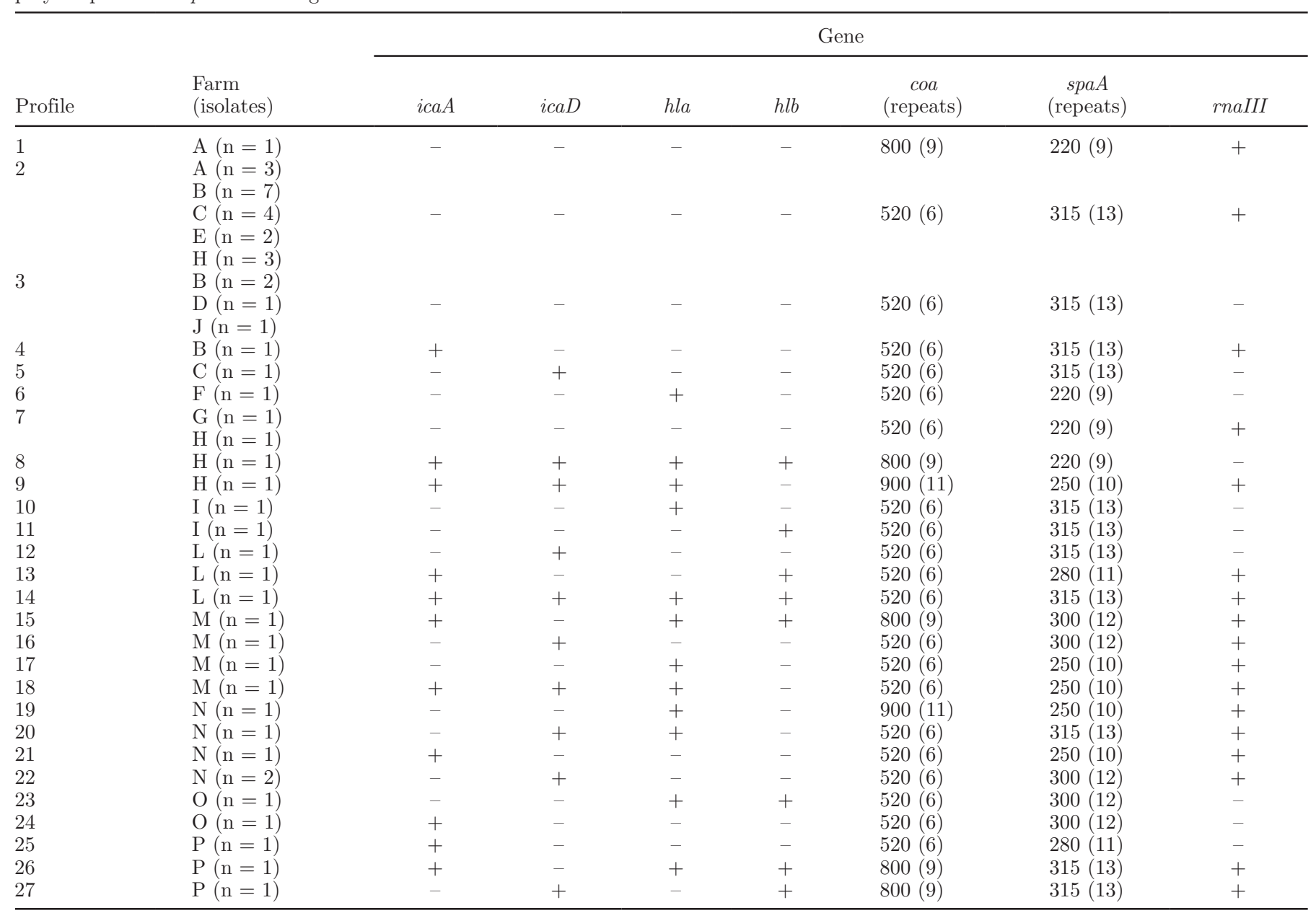

playing a role in cell-to-cell interactions during the process of biofilm formation (Götz, 2002). However, in the present study, statistical analysis showed no correlation between the levels of phenotypic slime production detected by the microplate and CRA tests and the presence of those genes. This result indicates that other mechanisms of slime production may coexist in Staph. aureus and, apparently, the intensity of its production is more related to the phenotypic characteristic expression specific to each strain.

Twenty-six (52\%) Staph. aureus were hemolytic and both $\alpha$ - and $\beta$-hemolysis were observed for $15(30 \%)$ isolates. From the 24 (48\%) non-hemolytic isolates, 3 were able to express hemolysis in the presence of a $\beta$-hemolytic strain. The interaction between $\alpha$ - and $\beta$-toxin increases the adherence to bovine mammary epithelial cells and the proliferation of Staph. aureus, thus contributing to the establishment of Staphylococcus strains in the mammary glands, as described pre- viously by Bownik and Siwicki (2008). In this study, $\beta$-hemolysin is present in $69 \%(18 / 26)$ of the hemolytic isolates, suggesting that this hemolysin may have an important role in the pathogenesis of mastitis, such as increasing permeability with progressive loss of cell surface charge in mammalian mammary glands cells (Coelho et al., 2009). The Multiplex PCR for the hla and $h l b$ genes showed positive results in $24 \%(12 / 50)$ and $16 \%(8 / 50)$ of the isolates, respectively. Additionally, $13 \%(3 / 23)$ of $\alpha$-hemolytic and $5.5 \%(1 / 18)$ of $\beta$-hemolytic isolates presented the $h l a$ and hlb genes, respectively. A total of $81 \%(21 / 26)$ of the isolates showed some type of hemolysin and were negative for both genes, suggesting the involvement of other genes, possibly related to the expression of these toxins, which are not amplified with the primers used in the present work. In our results, $12 \%(3 / 24)$ of the non-hemolytic Staph. aureus were able to express hemolysins in the presence of a $\beta$-hemolytic strain. This phenomenon can 
probably be explained by the production of a deltahemolysin, whose expression depends on the presence of a $\beta$-hemolytic isolate (Ali-Vehmas et al., 2001).

The PCR of the coa gene displayed 3 different size polymorphisms with approximately 520 bp for 43 $(86 \%)$ strains, 800 bp for $5(10 \%)$ strains, and $900 \mathrm{bp}$ for $2(4 \%)$ strains. According to Hookey et al. (1998) and based on these results, the calculated numbers of repeats were 6,9 , and 11 repeats, respectively. In a study performed by Lange et al. (1999) in southern Brazil, 7 different coa profiles were identified through PCR -2 of them accounted for more than $50 \%$ of the isolates - suggesting that, in some Brazilian regions, most cases of mastitis may be caused by similar Staph. aureus strains.

The amplification of the $\mathrm{X}$ region from the spaA gene yielded a single amplicon for each isolate, with the prevalent amplicon size being $315 \mathrm{bp}$ for 32 strains (64\%), 300 bp for 6 strains (12\%), $250 \mathrm{bp}$ for 5 strains (10\%), 220 bp for 5 strains (10\%), and 280 bp for 2 strains (4\%). Frénay et al. (1996) affirmed that spaA gene lengths $>260 \mathrm{bp}$ tend to be more associated with epidemic than with sporadic strains.

A total of 37 (74\%) of the investigated Staph. aureus isolates were positive for rnaIII. This gene, located in the agr locus, encodes the RNAIII molecule and regulates at least 15 genes encoding for potential virulence factors. The Agr mutants are nonpathogenic, are related to decreased synthesis of extracellular toxins and enzymes, and are, at the same time, related to an increased synthesis of adhesion molecules, such as coagulase and protein A (Gilot and van Leeuwen, 2004).

Staphylococcus aureus was isolated from milk samples collected over 15 dairy cattle farms, located in 5 different towns in the state of Rio de Janeiro. Twenty-seven profiles (Table 2) were established among the isolates, based on a remarkable variability detected in the studied genes and their polymorphic forms. The predominant profiles were 2,3 , and 7 , with a frequency rate of 38 , 8 , and $2 \%$, respectively, showing the absence of $i c a A$, $i c a D$, hla, and hlb genes as their most significant characteristic. The low percentage of studied genes among the isolates does not dismiss the important role played by these virulence factors; it emphasizes the need for detection of a more extensive range of virulence factors, as all of them were positive for the presence of the rnaIII gene. Other Staph. aureus isolates (50\%) also yielded different profiles, confirming the variability of this bacterium in the studied region. These results help in the understanding of the distribution of infectious Staph. aureus strains in Brazil and contribute to the establishment of preventive strategies to decrease the spread of infection.

\section{ACKNOWLEDGMENTS}

The authors are thankful to E. Reinoso, M. Demo, C. Bogni, and L. Odierno from Universidad de Rio Cuarto (Córdoba, Argentina). This study was supported by the National Council for Scientific and Technological Development (CNPq, Rio de Janeiro, Brazil) and Fundação de Amparo à Pesquisa do Estado do Rio de Janeiro (FAPERJ; process E-26/171.366/2006).

\section{REFERENCES}

Adhikari, R. P., G. M. Cook, I. Lamont, S. Lang, H. Heffernan, and J. M. B. Smith. 2002. Phenotypic and molecular characterization of community occurring, Western Samoan phage pattern methicillin-resistant Staphylococcus aureus. J. Antimicrob. Chemother. 50:825-831.

Ali-Vehmas, T., M. Vikerpuur, S. Pyörälä, and F. Atroshi. 2001. Characterization of hemolytic activity of Staphylococcus aureus strains isolated from bovine mastitic milk. Microbiol. Res. 155:339-344.

Arciola, C. R., L. Baldassarri, and L. Montanaro. 2001. Presence of $i c a A$ and $i c a D$ genes and slime production in a collection of staphylococcal strains from catheter-associated infections. J. Clin. Microbiol. 39:2151-2156.

Bownik, A., and A. J. Siwicki. 2008. Review paper: Effects of staphylococcal hemolysins on the immune system of vertebrates. Cent. Eur. J. Immunol. 33:87-90.

Christensen, G. D., W. A. Simpson, J. J. Younger, L. M. Baddour, F. F. Barrett, D. M. Melton, and E. H. Beachey. 1985. Adherence of coagulase-negative staphylococci to plastic tissue culture plates: A quantitative model for the adherence of staphylococci to medical devices. J. Clin. Microbiol. 22:996-1006.

Coelho, S. M. O., E. Reinoso, I. A. Pereira, L. C. Soares, M. Demo, C. Bogni, and M. M. S. Souza. 2009. Virulence factors and antimicrobial resistance of Staphylococcus aureus isolated from bovine mastitis in Rio de Janeiro. Pesqui. Vet. Bras. 29:369-374.

Demo, M. 1996. Caracterizacion y studios de patogenicidad de cepas dela genero Staphylococcus asiladas de leches mastiticas. Instituto de Microbiologia, Universidad Nacional de Rio Cuarto, Argentina.

Frénay, H., A. E. Bunschoten, L. M. Schouls, W. J. van Leeuwen, C. M. Vandenbroucke-Grauls, J. Verhoef, and F. R. Mooi. 1996. Molecular typing of methicillin-resistant Staphylococcus aureus on the basis of protein A gene polymorphism. Eur. J. Clin. Microbiol. Infect. Dis. 15:60-64.

Gilot, P., and W. van Leeuwen. 2004. Comparative analysis of agr locus diversification and overall genetic variability among bovine and human Staphylococcus aureus isolates. J. Clin. Microbiol. 42:1265-1269.

Godden, S. M., J. T. Jansen, K. E. Leslie, N. L. Smart, and D. F. Kelton. 2002. The effect of sampling time and sample handling on the detection of Staphylococcus aureus in milk from quarters with subclinical mastitis. Can. Vet. J. 43:38-42.

Götz, F. 2002. Staphylococcus and biofilms. Mol. Microbiol. 43:13671378 .

Hookey, J. V., J. F. Richardson, and B. D. Cookson. 1998. Molecular typing of Staphylococcus aureus based in PCR restriction fragment length polymorphism and DNA sequence analysis of the coagulase gene. J. Clin. Microbiol. 36:1083-1089.

Karahan, M., and B. Çetinkaya. 2007. Coagulase gene polymorphisms detected by PCR in Staphylococcus aureus isolated from subclinical bovine mastitis in Turkey. Vet. J. 174:428-431.

Koneman, E. W., S. D. Allen, W. M. Janda, P. C. Schreckenberger, and W. C. Winn Jr. 2005. Color Atlas and Textbook of Diagnostic Microbiology. 6th ed. Editora Meds, Rio de Janeiro, Brazil.

Koreen, L., S. V. Ramaswamy, E. A. Graviss, S. Naidich, J. M. Musser, and B. N. Kreiswirth. 2004. spa typing method for discriminating among Staphylococcus aureus isolates: Implications for use of 
a single marker to detect genetic micro- and macrovariation. J. Clin. Microbiol. 42:792-799.

Lange, C., M. Cardoso, D. Senczek, and S. Schwarz. 1999. Molecular subtyping of Staphylococcus aureus isolates from cases of bovine mastitis in Brazil. Vet. Microbiol. 67:127-141.

Linehan, D., J. Etienne, and D. Sheehan. 2003. Relationship between haemolytic and sphingomyelinase activities in a partially purified $\beta$-like toxin from Staphylococcus schleiferi. FEMS Immunol. Med. Microbiol. 36:95-102.

Lyon, G. J., P. Mayville, T. W. Muir, and R. P. Novick. 2000. Rational design of a global inhibitor of virulence response in Staphylococcus aureus, based in part on localization of the site of inhibition to the receptor-histidine kinase, AgrC. Proc. Natl. Acad. Sci. USA 97:13330-13335

Novick, R. P. 2000. Pathogenicity factors and their regulation. Pages 392-407 in Gram-Positive Pathogens. V. A. Fischetti, R. P.
Novick, J. J. Ferretti, D. A. Portnoy, and J. I. Rood, ed. American Society for Microbiology Press, Washington, DC.

Reinoso, E. B. 2004. Análisis epidemiológico y molecular de cepas de Staphylococcus aureus de distintos orígenes. PhD Thesis. Instituto de Microbiología, Universidad Nacional de Rio Cuarto, Argentina. Straub, J. A., C. Hertel, and W. P. Hammes. 1999. A 23S rDNAtargeted polymerase chain reaction-based system for detection of Staphylococcus aureus in meat started cultures and dairy products. J. Food Prot. 62:1150-1156.

Vasudevan, P., M. K. M. Nair, T. Annamalai, and K. S. Venkitanarayanan. 2003. Phenotypic and genotypic characterization of bovine mastitis isolates of Staphylococcus aureus for biofilm formation. Vet. Microbiol. 92:179-185. 